
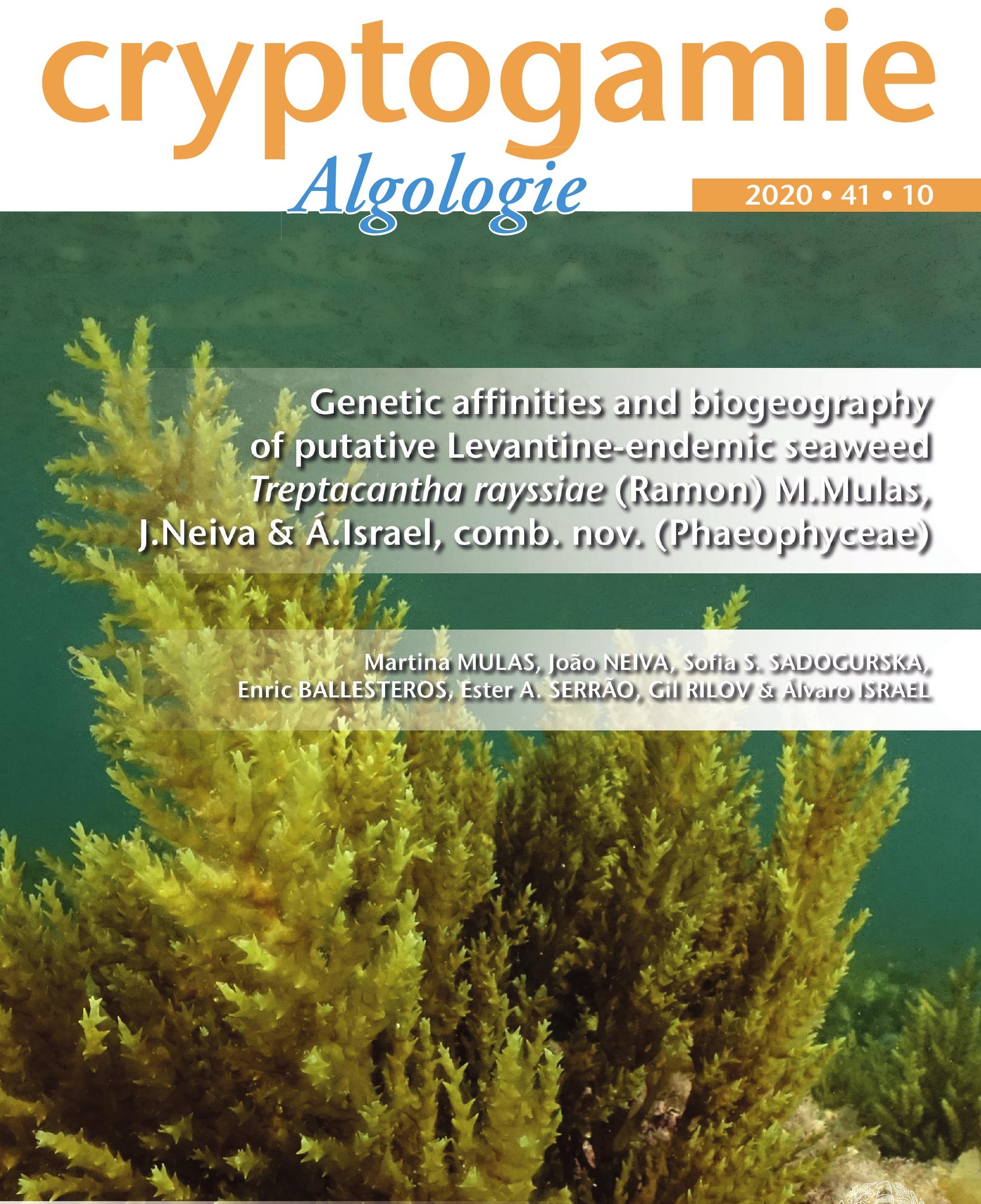
DiRECTEUR DE LA PUBLICATION / PUBLICATION DIRECTOR: Bruno DAVID

Président du Muséum national d'Histoire naturelle

RÉDACTRICE EN CHEF / EDITOR-IN-CHIEF : Line LE GALL

Muséum national d'Histoire naturelle

ASSISTANTE DE RÉDACTION / ASSISTANT EDITOR : Audrina NEVEU (algo@cryptogamie.com)

Mise en PAge / PAge LAyout : Audrina NEVEU

RÉdACTEURS ASSOCIÉS / AsSOCIATE EDITORS

Ecoevolutionary dynamics of algae in a changing world

Stacy KRUEGER-HADFIELD

Department of Biology, University of Alabama, 1300 University Blvd, Birmingham, AL 35294 (United States)

Jana KULICHOVA

Department of Botany, Charles University, Prague (Czech Repubwlic)

Cecilia TOTTI

Dipartimento di Scienze della Vita e dell'Ambiente, Università Politecnica delle Marche, Via Brecce Bianche, 60131 Ancona (Italy)

Phylogenetic systematics, species delimitation \& genetics of speciation

Sylvain FAUGERON

UMI3614 Evolutionary Biology and Ecology of Algae, Departamento de Ecología, Facultad de Ciencias Biologicas,

Pontificia Universidad Catolica de Chile, Av. Bernardo O’Higgins 340, Santiago (Chile)

Marie-Laure GUILLEMIN

Instituto de Ciencias Ambientales y Evolutivas, Universidad Austral de Chile, Valdivia (Chile)

Diana SARNO

Department of Integrative Marine Ecology, Stazione Zoologica Anton Dohrn, Villa Comunale, 80121 Napoli (Italy)

Comparative evolutionary genomics of algae

Nicolas BLOUIN

Department of Molecular Biology, University of Wyoming, Dept. 3944, 1000 E University Ave, Laramie, WY 82071 (United States)

Heroen VERBRUGGEN

School of BioSciences, University of Melbourne, Victoria, 3010 (Australia)

Algal physiology \& photosynthesis

Janet KÜBLER

California State University Northridge, Department of Biology, California State University, Northridge, CA $91330-8303$ (United States)

Prokaryotic algae

Nico SALMASO

IASMA Research and Innovation Centre, Fondazione Mach-Istituto Agrario di S. Michele all'Adige, Limnology and River Ecology,

Via E. Mach, 1, 38010 San Michele all'Adige, Trento (Italy)

Vitor VASCONCELOS

Faculdade de Ciências da Universidade do Porto and CIIMAR, Rua do Campo Alegre, s/n, 4169-007 Porto (Portugal)

COUVERTURE / COVER:

Treptacantha rayssiae (Ramon) M.Mulas, J.Neiva \& A.Israel, comb. nov.

Photo credit: Dar Golomb.

Cryptogamie, Algologie est indexé dans / Cryptogamie, Algologie is indexed in:

- Aquatic Sciences \& Fisheries Abstracts Part I.

- Biological Abstracts

- Chemical Abstracts

- Current Contents

- Marine Science Contents Tables (FAO)

- Science Citation Index

- Publications bibliographiques du CNRS (Pascal).

Cryptogamie, Algologie est distribué en version électronique par / Cryptogamie, Algologie is distributed electronically by:

- BioOne ${ }^{\circledR}$ (http://www.bioone.org/loi/crya)

Cryptogamie, Algologie est une revue en flux continu publiée par les Publications scientifiques du Muséum, Paris Cryptogamie, Algologie is a fast track journal published by the Museum Science Press, Paris

Les Publications scientifiques du Muséum publient aussi / The Museum Science Press also publishes: Adansonia, Geodiversitas, Zoosystema, Anthropozoologica, European Journal of Taxonomy, Naturae, Cryptogamie sous-sections Bryologie, Mycologie, Comptes Rendus Palevol.

Diffusion - Publications scientifiques Muséum national d'Histoire naturelle

CP $41-57$ rue Cuvier F-75231 Paris cedex 05 (France)

Tél. : 33 (0)1 40794805 / Fax: 33 (0)1 40793840

diff.pub@mnhn.fr / http://sciencepress.mnhn.fr

(c) Publications scientifiques du Muséum national d'Histoire naturelle, Paris, 2020

ISSN (imprimé / print) : 0181-1568 / ISSN (électronique / electronic): 1776-0984 


\title{
Genetic affinities and biogeography of putative Levantine-endemic seaweed Treptacantha rayssiae (Ramon) M.Mulas, J.Neiva \& Á.Israel, comb. nov. (Phaeophyceae)
}

\author{
Martina MULAS* \\ Israel Oceanographic \& Limnological Research, The National Institute \\ of Oceanography, P.O. Box 8030, 31080 Haifa (Israel) \\ and The Leon $\mathrm{H}$. Charney School of Marine Sciences, \\ University of Haifa, Mt. Carmel, Haifa (Israel) \\ martina.mulas@ocean.org.il (corresponding author) \\ * equal contributions
}

João NEIVA*

Centro de Ciências do Mar (CCMAR), Universidade do Algarve

- Campus de Gambelas, Faro (Portugal)

jmneiva@ualg.pt (corresponding author)

* equal contributions

Sofia S. SADOGURSKA

M.G. Kholodny Institute of Botany, Department of Phycology,

Lichenology and Bryology, National Academy of Science of Ukraine, Kyiv (Ukraine)

Enric BALLESTEROS

Centre d'Estudis Avançats de Blanes (CSIC), 17300 Blanes, Girona (Spain)

Ester A. SERRÃO

Centro de Ciências do Mar (CCMAR), Universidade do Algarve

- Campus de Gambelas, Faro (Portugal)

Gil RILOV**

Israel Oceanographic \& Limnological Research, The National Institute of Oceanography, P.O. Box 8030, 31080 Haifa (Israel) and The Leon $\mathrm{H}$. Charney School of Marine Sciences,

University of Haifa, Mt. Carmel, Haifa (Israel)

** equal contributions

Álvaro ISRAEL**

Israel Oceanographic \& Limnological Research, The National Institute of Oceanography, P.O. Box 8030, 31080 Haifa (Israel)

** equal contributions

Mulas M., Neiva J., Sadogurska S. S., Ballesteros E., Serrão E. A., Rilov G. \& Israel Á. 2020. - Genetic affinities and biogeography of putative Levantine-endemic seaweed Treptacantha rayssiae (Ramon) M.Mulas, J.Neiva \& Á.Israel, comb. nov. (Phaeophyceae). Cryptogamie, Algologie 41 (10): 91-103. https://doi.org/10.5252/cryptogamie-algologie2020v41a10. http://cryptogamie.com/algologie/41/10 


\section{KEY WORDS \\ Brown algae, Cystoseira rayssiae, $\mathrm{COI}$,
rocky-shore assemblages,
Israel, \\ Mediterranean Sea, new combination.}

\section{MOTS CLÉS \\ Algues brunes, Cystoseira rayssiae, COI, assemblages de rivages \\ rocheux,
Israël, \\ mer Méditerranée, combinaison nouvelle.}

\begin{abstract}
Cystoseira sensu lato (Ochrophyta) forests are important habitat formers in the Mediterranean Sea, but they have mostly been studied in the western basin where many species are under decline. In the eastern basin, where fewer species occur, Cystoseira rayssiae Ramon was described in the year 2000 as an endemic species based on morphological characteristics from herbaria samples collected on the Israeli coast. No further investigations have been conducted on this peculiar species since, but recently it has been recorded in contiguous Lebanon and outside the Mediterranean. Our work was aimed at confirming the taxonomic validity and endemic nature of this species, including its position among the recently split Cystoseira sensu stricto, Carpodesmia Greville and Treptacantha Kützing genera, by sequencing the mitochondrial COI gene and by examining morphological characteristics in samples from three different sites in northern Israel. Notwithstanding considerable morphological plasticity, molecular analyses revealed a single unique COI sequence. Phylogenetic analyses show that Cystoseira rayssiae belongs to the resurrected genus Treptacantha and hence, the new combination Treptacantha rayssiae (Ramon) M.Mulas, J.Neiva \& Á.Israel, comb. nov., is proposed. Unique sequences and a restricted range support its Levantine-endemic status. Intriguing extra-Mediterranean reports from the Red Sea and the Persian Gulf are probably misidentifications rather than reflecting a disjunct distribution or recent invasion.
\end{abstract}

\section{RÉSUMÉ}

Affinités génétiques et biogéographie du peigne d'algues marines Levantine-endémique Treptacantha rayssiae (Ramon) M.Mulas, J.Neiva et A.Israel, comb. nov. (Phaeophyceae).

Les forêts de Cystoseira sensu lato (Ochrophyta) sont d'importantes formes d'habitat dans la mer Méditerranée, mais elles ont surtout été étudiées dans le bassin occidental où de nombreuses espèces sont en déclin. Dans le bassin oriental, où moins d'espèces sont présentes, Cystoseira rayssiae Ramon a été décrite en l'an 2000 comme une espèce endémique sur la base des caractéristiques morphologiques d'échantillons d'herbiers prélevés sur la côte israélienne. Aucune autre enquête n'a été menée sur cette espèce particulière depuis, mais récemment, elle a été enregistrée dans le Liban contigu et en dehors de la Méditerranée. Notre travail visait à confirmer la validité taxonomique et la nature endémique de cette espèce, y compris sa position parmi les genres Cystoseira sensu stricto, Carpodesmia Greville et Treptacantha Kützing récemment divisés, en séquençant le gène mitochondrial COI et en examinant les caractéristiques morphologiques dans des échantillons provenant de trois sites différents dans le nord d'Israël. Malgré une plasticité morphologique considérable, les analyses moléculaires ont révélé une seule et unique séquence COI. Les analyses phylogénétiques montrent que Cystoseira rayssiae appartient au genre ressuscité Treptacantha et, par conséquent, la nouvelle combinaison Treptacantha rayssiae (Ramon) M.Mulas, J.Neiva \& Á.Israel, comb. nov., est proposée. endémie levantine. D’intrigants rapports extra-méditerranéens provenant de la mer Rouge et du golfe Persique sont probablement des erreurs de reconnaissance plutôt que le reflet d'une distribution disjointe ou d'une invasion récente.

\section{INTRODUCTION}

In the Mediterranean Sea, macroalgal forests composed of species of the genus Cystoseira sensu lato dominate many benthic reef communities from the low intertidal down to a few tens of meters (Cormaci et al. 2012; Taşkin et al. 2012). They play crucial roles in ecosystem functioning and provide both food and shelter for many reef species (Bulleri et al. 2002; Chemineé et al. 2013). Due to direct and indirect human pressure, many Cystoseira sensu lato forests have gradually declined over the last decades along Atlantic and Mediterranean coasts (Vergés et al. 2014b; Mineur et al. 2015; Thibaut et al. 2015; Valdazo et al. 2017). Because of their vulnerability and ongoing degradation, Cystoseira species (with the exception of C. compressa (Esper) Gerloff \& Nizamuddin) are protected by the Barcelona Convention (UNEP/MAP-RAC/SPA 2012).
In the eastern Mediterranean, the knowledge about the complex of species included in the genus Cystoseira s.l. is still very limited and more studies are required to clarify species pools, distributions and threats. Along the Israeli Mediterranean coast, for example, the status of this group was unclear until recently (Israel \& Einav 2017). Surveys in northern Israel indicate that canopy-forming brown seaweeds are today in general a rare sight on shallow reefs, likely due to overgrazing by the two invasive rabbitfish Siganus luridus (Rüppell) and S. rivulatus Forsskål \& Niebuhr (Lundberg et al. 1999; Bariche 2006; Rilov 2016; Rilov et al. 2018), and to the rising water temperature that shortens their growth season by one-two months (Rilov et al. 2020). A similar conclusion was inferred from field fish exclusion experiments conducted on Cystoseira spp. in Turkey (Sala et al. 2011; Vergés et al. 2014a, b).

Three Cystoseira sensu lato species have been so far reported to occur along the Israeli Mediterranean Sea coast: $C$. compressa 
A

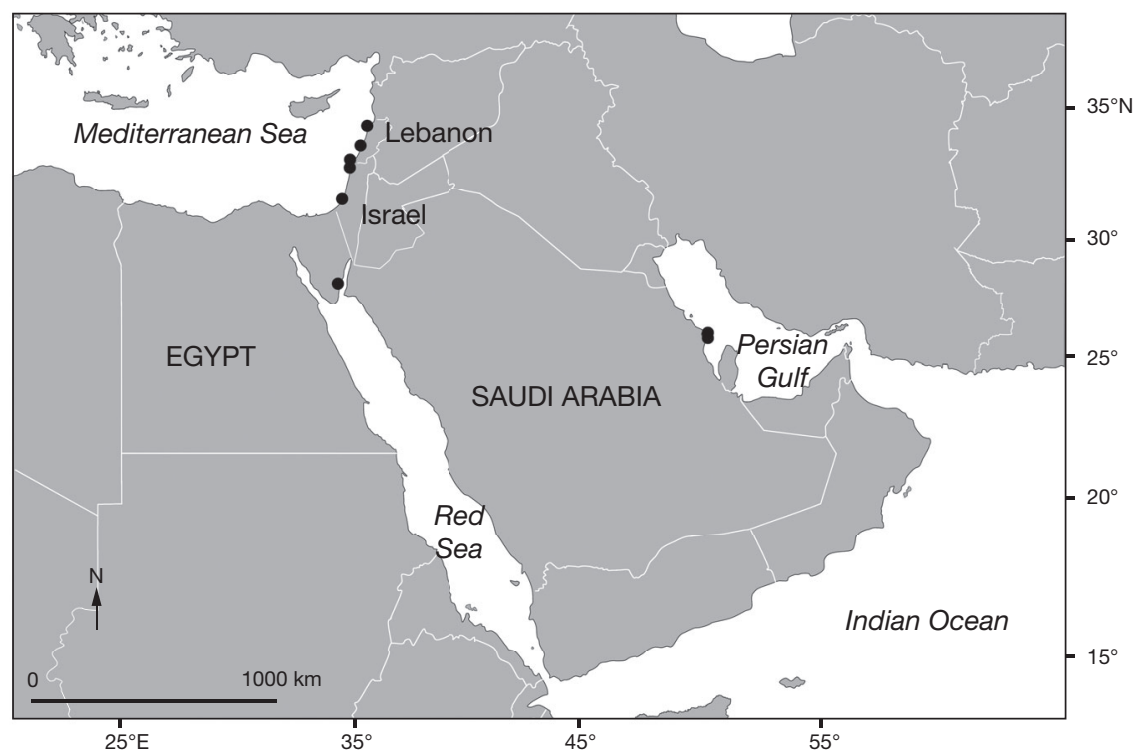

$\mathrm{B}$

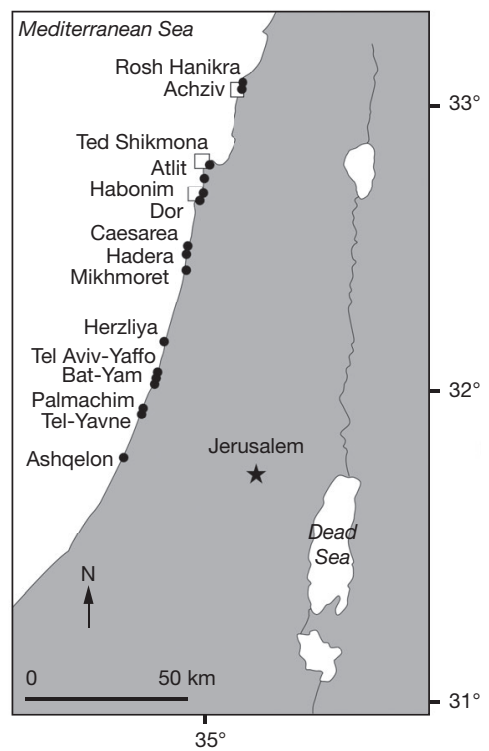

FIG. 1. - Reported distribution of Treptacantha rayssiae (Ramon) M.Mulas, J.Neiva \& Á.Israel, comb. nov. (synonym of Cystoseira rayssiae): A, occurrence records based on literature records; B, distribution (black dots) in Israeli Mediterranean Sea shores as reported in Ramon (2000) based on herbaria collections. The squares indicate the origin of samples analyzed in this study: Achziv (Gesher Haziv), Tel Shikmona and HaBonim.

(Esper) Gerloff \& Nizamuddin, C. schiffneri Hamel [regarded by some authors as a form of $C$. foeniculacea i.e., $C$. foeniculacea (Linnaeus) Greville f. schiffneri (Hamel) Gómez Garreta et al.] and $C$. rayssiae Ramon (Einav \& Israel 2008). The first two are widely distributed in the Mediterranean Sea (Cormaci et al. 2012; Taskin et al. 2012; Bouafif et al. 2016). By comparison, $C$. rayssiae was described only in the year 2000 as an endemic species based on morphological characteristics from herbaria samples collected throughout the entire Israeli coast (Rosh HaNikra in the north to Ashqelon in the south) between 1906-1989 (Ramon 2000). This species was later reported also to the north of Israel, on the Lebanese coast (Badreddine et al. 2018), and also from the Red Sea and the Persian Gulf (Abdel-Kareem 2009; Abdel-Raouf et al. 2015), questioning its putative Levantine-endemic status.

Draisma et al. (2010) showed that Cystoseira s.l. was polyphyletic and composed by at least six distinct lineages, including then-resurrected Stephanocystis Trevisan, Polycladia Montagne and Sirophysalis Kützing. The three remaining lineages, with overlapping distributions in the North-Eastern Atlantic/Mediterranean, were maintained within Cystoseira until very recently, when Orellana et al. (2019) formalized their split. Based on morphological and DNA evidence and nomenclatural precedence, they proposed maintaining Cystoseira sensu stricto for the species C. compressa (Esper) Gerloff \& Nizamuddin, C. foeniculacea (Linnaeus) Greville (type species) and C. humilis Schousboe ex Kützing; transferring C. abies-marina (S.G.Gmelin) C.Agardh, C. algeriensis Feldmann, C. baccata (S.G.Gmelin) P.C.Silva, C. elegans Sauvageau, C. mauritanica Sauvageau, C. spinosa Sauvageau, C. nodicaulis (Withering) M.Roberts and C. usneoides (Linnaeus) M.Roberts to the resurrected genus Treptacantha Kützing [type species Treptacantha abies- marina (S.G.Gmelin) Kützing] and C. amentacea (C.Agardh) Bory, C. brachycarpa J.Agardh, C. crinita Duby, C. mediterranea Sauvageau, C. tamariscifolia (Hudson) Papenfuss and C. zosteroides (Turner) C.Agardh to the resurrected genus Carpodesmia Greville [type species Carpodesmia zosteroides (Turner) Greville]. The assignment of many other Cystoseira species to these three genera however remains unassessed.

In this study, we investigate the genetic validity and evolutionary affinities of Cystoseira rayssiae from Israel, including its position within Cystoseira sensu stricto/Treptacantha/Carpodesmia genera. We also provide an updated morphological description, including a first assessment of its morphological plasticity, and make a critical appraisal of its distribution and potential origins based on published records and biogeography of the genus.

\section{MATERIAL AND METHODS}

\section{SAMPLES COLLECTION AND GENETIC IDENTIFICATION}

Morphologically variable samples of Cystoseira rayssiae were collected in 2018 and 2019 along the Northern Israeli coast. Samples for genetic analyses were collected from three representative sites - Achziv (333’22.23”N, 356'6.82”E), Tel Shikmona, Haifa (32 $\left.49^{\prime} 32.97^{\prime \prime} \mathrm{N}, 34^{\circ} 57^{\prime} 19.08^{\prime \prime} \mathrm{E}\right)$ and Dor

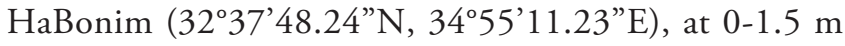
depth (Fig. 1B). Specimens from all three sites were examined in the original species description (Appendix in Ramon 2000). Tel Shikmona is the only known dense shallow forest along the Israeli coast, but the species was observed and collected at tidal pools in Achziv and in both tidal pools and as scattered subtidal specimens in HaBonim. Samples for molecular analysis were stored in silica-gel and voucher 
specimens were deposited in the Israel Oceanographic and Limnological Research Institute (Haifa, Israel) - Seaweed Herbarium "IOLR" (Index Herbariorum) (Appendix 2). DNA was extracted from four individuals. The two specimens collected from Tel Shikmona were extracted at CCMAR (Portugal) using the commercial Nucleospin 96 Plant II kit (Macherey-Nagel, Düren, Germany) and the other two, respectively from Achziv and HaBonim, at IOLR (Israel) according to Douek et al. (2002). A fragment of the mtDNA gene COI (cytochrome $c$ oxidase) was amplified using the primer pairs GazF2/GazR2 (5'-CCAACCAYAAAGATATWGGTAC-3'/ 5'-GGATGACCAAARAACCAAAA-3') as in Silberfeld et al. (2010), following the PCR temperature profile: $95^{\circ} \mathrm{C}$, $5 \mathrm{~min} ;\left(95^{\circ} \mathrm{C}, 30 \mathrm{~s} ; 45^{\circ} \mathrm{C}, 45 \mathrm{~s} ; 72^{\circ} \mathrm{C}, 1 \mathrm{~min}\right) \times 35$ cycles; $72^{\circ} \mathrm{C}, 10 \mathrm{~min}$. Fragments were sequenced in an ABI PRISM 3130xl automated capillary sequencer (Applied Biosystems) at CCMAR (Portugal), and commercially (Macrogen Inc., South Korea). The newly generated sequences were deposited in GenBank (Benson et al. 2017).

Sequences were aligned in Geneious v.11.03 with published (retrieved from GenBank; https://www.ncbi.nlm.nih. gov/genbank/) and new sequences (amplification as above) of other Cystoseira sensu lato (including Cystoseira s.s., Treptacantha and Carpodesmia) and the related genera Bifurcaria Stackhouse, Stephanocystis Trevisan and Sargassum C.Agardh (Table 1; Appendix 1). Two data-sets were analyzed separately for model selection, implementation and analyses (Bayesian, ML) - a smaller dataset restricted to Treptacantha species and another one including multiple Sargassaceae genera.

Nucleotide substitution models (three substitution schemes, unique sequences only) were assessed with jModelTest v.2.6.5 (Darriba et al. 2012) using ML optimized tree for likelihood calculations and Best tree search, and best-fit models were selected as the best-ranked model selected by both the Akaike and Bayesian information criterion. Bayesian phylogenetic analyses were run with MrBayes v.3.2.6 (Ronquist et al. 2012). Two parallel MCMC Monte Carlo searches were run for $10^{6}$ generations, sampling trees and parameters every 100 generations. For each data set, the number of substitution rates, among-site rate variation and base frequency priors were set according to the substitution model selected, leaving the remaining options as default. Run length sufficiency was confirmed by inspecting the average standard deviation of split frequencies between runs (ASDSF <0.02). $10^{5}$ generations (1000 trees in each run) were discarded as burn-in, and the remaining 18000 sampled trees were used to produce consensus trees and to calculate branch posterior probabilities. Maximum likelihood analyses were performed with PhyML v.3.0 using the same substitution models in the ATGC bioinformatics platform (http://www.atgc-montpellier. $\mathrm{fr} /$ phyml/). Nodal support was calculated using 1000 bootstrap replicates. Trees were rooted using the Stephanocystis/C. compressa/Sargassum branch as outgroup (Draisma et al. 2010). The same analyses were run for a smaller subset of species closely related to Cystoseira rayssiae (genus Treptacantha, see below). Genealogic relationships were further illustrated with a network calculated with PopART v.1.7 (http://popart.otago. ac.nz) using the Median-Joining (MJ) algorithm (Bandelt et al. 1999). The original alignments and the phylogenetic tree are deposited in the Dryad repository and public available (https://doi.org/10.5061/dryad.sj3tx9617).

\section{Thalli morphology}

Morphological descriptions were conducted on the vouchers deposited in the "IOLR" Seaweed Herbarium, in the "HUJ" National Herbarium of the Hebrew University, and on additional 20 samples collected from Tel Shikmona, Achziv and HaBonim. The size, shape and diameter of the holdfast and main axis were measured, and branch characteristics were annotated. Photo-images were captured using a DS-Fi3 camera installed on a SMZ745T Nikon stereomicroscope and digital camera Olympus Tough TG-620. Fragments of primary branches were selected from fresh and frozen thalli (respectively, Cystoseira rayssiae (Ramon) from Tel Shikmona and from Achziv) and crossed sections were prepared using a CM 1850 Leica cryostat. Microscopic characteristics such as medullary, cortical and meristoderm cells were observed and photographed with a SZX16 Olympus stereomicroscope and/ or under a $20 \mu \mathrm{m}$ magnification under an Olympus BX50 microscope, both connected to a SC-180 Olympus camera.

\section{Species distribution}

Google Scholar, Scopus and GBIF were used as queries to collate all available reported occurrence records of $C$. rayssiae. These data, our field observations and monitoring along the Israel coast were used to produce a map of its apparent global distribution (Fig. 1A).

\section{RESULTS AND DISCUSSION}

\section{GENETIC AFFINITIES AND GENERAL MORPHOLOGY}

The final COI alignment was 627 base-pair long, with no indels, and included 65 sequences corresponding to 18 species-level taxa (Fig. 2, see Table 1 and Appendix 1 for new and previously published GenBank accession records). The sequence of all samples of $C$. rayssiae were identical (GenBank accession MK370729), despite clear morphological differences among them. The best substitution model for the final dataset (22 unique sequences) was HKY + I + G. Genetic data confirmed that $C$. rayssiae belongs to the well supported Treptacantha genus (sensu Orellana et al. 2019; synonym of Cystoseira-6 sensu Draisma et al. 2010; synonym of Cystoseira-II Bruno de Sousa et al. 2019), together with T. baccata (S.G.Gmelin) Orellana and Sansón, T. usneoides (Linnaeus) Orellana and Sansón, T. barbata (Stackhouse) Orellana and Sansón, T. nodicaulis (Withering) Orellana and Sansón, T. ballesterosii Orellana and Sansón, T. mauritanica (Sauvageau) Orellana and Sansón, and another tophulose (i.e., with characteristic reserve structures called tophules) Treptacantha sp. from the eastern Mediterranean (Crete) (Fig. 2). When the sequences were analyzed with Treptacantha spp. (HKY + I, seven unique sequences), the closer relationship of $C$. rayssiae with the latter four species became more apparent (Appendix 1). 
A

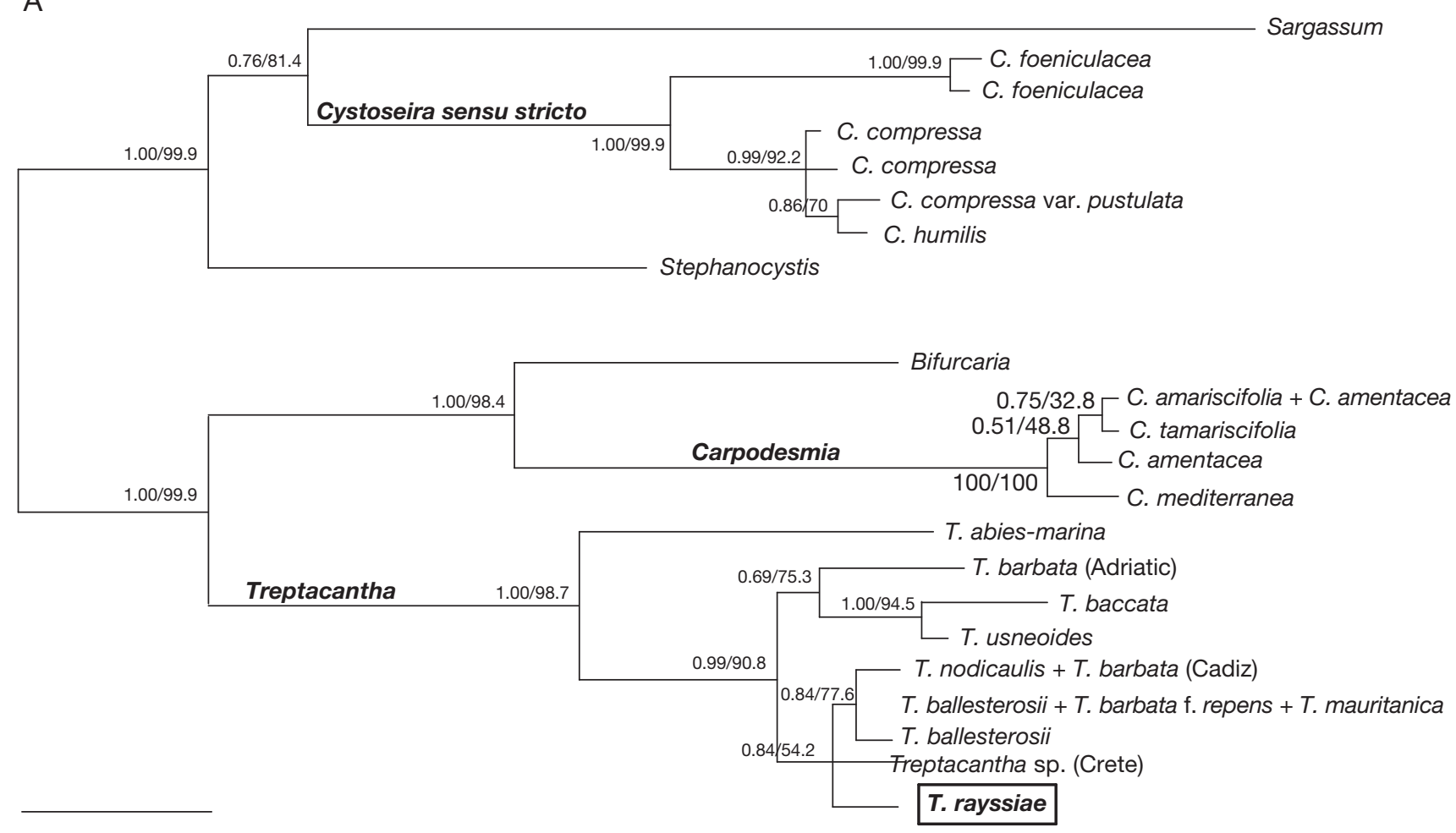

B

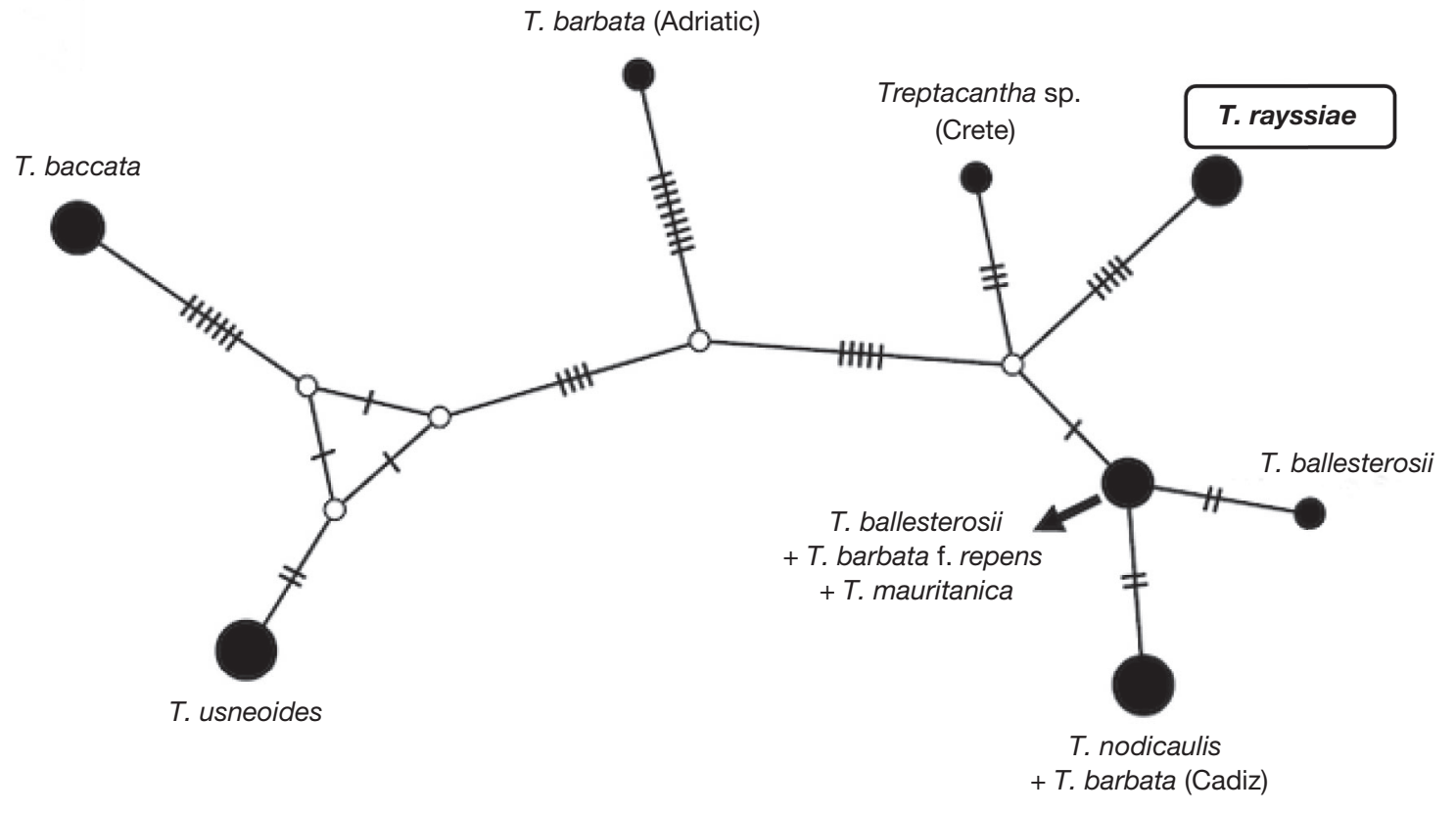

FIG. 2. - Phylogenetic affinities of Treptacantha rayssiae (Ramon) M.Mulas, J.Neiva \& Á.Israel, comb. nov. (synonym of C. rayssiae): A, bayesian 50\% majority-rule consensus COI tree of selected species of Cystoseira sensu lato (including Cystoseira sensu stricto, Carpodesmia Greville and Treptacantha Kützing) and related genera, showing the phylogenetic position of Treptacantha rayssiae (Ramon) M.Mulas, J.Neiva \& A.Israel, comb. nov. Numbers above the branches are Bayesian posterior probabilities (>0.50) and maximum likelihood bootstrap support values, respectively. The outgroup used was represented by Stephanocystis Trevisan, C. compressa (Esper) Gerloff \& Nizamuddin and Sargassum C.Agardh; B, neighbour-joining network of COI sequences of T. rayssiae (Ramon) M.Mulas, J.Neiva \& Á.Israel, comb. nov., and related taxa. Terminal black circles correspond to unique sequences/taxa and are sized to their frequency. Small white circles represent internal nodes and perpendicular dashes along branches represent unique base-pair mutations between sequences/taxa. Branch lengths not to scale. Scale bar: A, 0.02 BIPP (Bayesian Inference Posterior Probability). 
TABLE 1. - Geographic origin (decimal degrees), collection details, accession number and sequence quality of samples processed in this study.

\begin{tabular}{|c|c|c|c|c|c|c|c|c|}
\hline Species & $\begin{array}{l}\text { Collection } \\
\text { site }\end{array}$ & $\begin{array}{l}\text { Latitude } \\
\text { /Longitude }\end{array}$ & Collector & Date & $\begin{array}{l}\text { GenBank } \\
\text { code }\end{array}$ & $\begin{array}{l}\text { Herbarium } \\
\text { accession }\end{array}$ & $\begin{array}{c}\# \\
\text { sequences }\end{array}$ & $\begin{array}{c}\% \text { bases } \\
\text { high quality }\end{array}$ \\
\hline Sargassum sp. & $\begin{array}{l}\text { Tel Shikmona, } \\
\text { Haifa, Israel }\end{array}$ & $\begin{array}{l}32^{\circ} 49^{\prime} 32.97^{\prime \prime} \mathrm{N} \\
\quad / 34^{\circ} 57^{\prime} 19.08^{\prime \prime} \mathrm{E}\end{array}$ & M. Mulas & V.2018 & MK370733 & $\begin{array}{l}\text { IOLR- } \\
\text { MM00630 }\end{array}$ & 1 & $97.80 \%$ \\
\hline Cystoseira compressa & $\begin{array}{l}\text { Tel Shikmona, } \\
\text { Haifa, Israel }\end{array}$ & $\begin{array}{l}32^{\circ} 49^{\prime} 32.97^{\prime \prime} \mathrm{N} \\
\quad / 34^{\circ} 57^{\prime} 19.08^{\prime \prime} \mathrm{E}\end{array}$ & M.Mulas & IV.2018 & MK388673 & $\begin{array}{l}\text { IOLR- } \\
\text { MM00640 }\end{array}$ & 1 & $97.80 \%$ \\
\hline C. foeniculacea & $\begin{array}{l}\text { Mades, Crete, } \\
\text { Greece }\end{array}$ & $\begin{array}{c}35^{\circ} 23^{\prime} 57.42^{\prime \prime} \mathrm{N} \\
/ 14^{\circ} 2^{\prime} 1.89^{\prime \prime} \mathrm{E}\end{array}$ & J. Neiva & V.2018 & MK370732 & $\begin{array}{l}\text { João Neiva, } \\
\text { Personal } \\
\text { Herbarium } \\
\text { Faro, Algarve, } \\
\text { Portugal }\end{array}$ & 1 & $94.50 \%$ \\
\hline $\begin{array}{l}\text { Treptacantha rayssiae, } \\
\text { comb. nov. }\end{array}$ & $\begin{array}{l}\text { Tel Shikmona, } \\
\text { Haifa, Israel }\end{array}$ & $\begin{array}{l}32^{\circ} 49^{\prime} 32.97^{\prime \prime} \mathrm{N} \\
\quad / 34^{\circ} 57^{\prime} 19.08^{\prime \prime} \mathrm{E}\end{array}$ & M. Mulas & IV.2018 & MK370729 & $\begin{array}{l}\text { IOLR- } \\
\text { MM00641 } \\
\text { MM00642 }\end{array}$ & 2 & $\begin{array}{l}95.9 \%, \\
97.5 \%\end{array}$ \\
\hline T. rayssiae, comb. nov. & Achziv, Israel & $\begin{array}{l}33^{\circ} 3^{\prime} 22.23^{\prime \prime} \mathrm{N} \\
/ 35^{\circ} 6^{\prime} 6.82^{\prime \prime} \mathrm{E}\end{array}$ & S. Sadogurska & V.2019 & MK370729 & $\begin{array}{l}\text { IOLR - } \\
\text { AmR1652019 }\end{array}$ & 1 & $88 \%$ \\
\hline T. rayssiae, comb. nov. & HaBonim, Israel & $\begin{array}{l}32^{\circ} 37^{\prime} 48.24^{\prime \prime} \mathrm{N} \\
\quad / 34^{\circ} 55^{\prime} 11.23^{\prime \prime} \mathrm{E}\end{array}$ & S. Sadogurska & IV.2019 & MK370729 & $\begin{array}{l}\text { IOLR - } \\
\text { BS5942019 }\end{array}$ & 1 & $73.70 \%$ \\
\hline T. ballesterosii & $\begin{array}{l}\text { Cabrera, } \\
\text { Baleares, Spain }\end{array}$ & $\begin{array}{l}39^{\circ} 12^{\prime} 23.82^{\prime \prime} \mathrm{N} \\
\quad / 2^{\circ} 58^{\prime} 45.47 " \mathrm{E}\end{array}$ & E. Ballesteros & $\mathrm{XI} .2017$ & MK370731 & - & 1 & $98 \%$ \\
\hline Treptacantha sp. & $\begin{array}{l}\text { Mades, Crete, } \\
\text { Greece }\end{array}$ & $\begin{array}{l}35^{\circ} 23^{\prime} 57.42^{\prime \prime} \mathrm{N} \\
/ 14^{\circ} 2^{\prime} 1.89^{\prime \prime} \mathrm{E}\end{array}$ & J. Neiva & V.2018 & MK370730 & $\begin{array}{l}\text { João Neiva, } \\
\text { Personal } \\
\text { Herbarium } \\
\text { Faro, Algarve, } \\
\text { Portugal }\end{array}$ & 1 & $97.30 \%$ \\
\hline
\end{tabular}

COI sequences of $C$. rayssiae were, however, unique and divergent (six-eight substitutions) from these other related species (Fig. 2A, B), much more than other Treptacantha (e.g. T. nodicaulis/T. ballesterosii, two substitutions, see Fig. 2B) and Sargassum (e.g. Amaral-Zettler et al. 2017) species complexes. These results indicate that $C$. rayssiae is unique and belongs unequivocally to the resurrected genus Treptacantha, and thus we propose the new combination:

Treptacantha rayssiae (Ramon) M.Mulas, J.Neiva \& Á.Israel, comb. nov.

Cystoseira rayssiae Ramon, Israel Journal of Plant Sciences 48: 59 (English), 61 (Latin); figs 1-5 (fig. 1: holotype) (1970) (basionym).

TYPe MATERIAL. - Holotype. HUJ (Ashqelon, Israel; 23.V. 1953).

\section{DESCRIPTION}

The morphological characteristics of this species along the Israeli coast are well in accordance with the features of the genus as described by Orellana et al. (2019), although Ramon herself noted that the species exhibits considerable morphological plasticity (Figs 3; 4). Treptacantha rayssiae (Ramon) M.Mulas, J.Neiva \& Á.Israel, comb. nov., shows a tophulose, non-caespitose habit, growing up to $c .30 \mathrm{~cm}$ high (Figs 3A; 4A). The thallus is attached to the substrate by a basal disc from which a cylindrical simple or branched axis grows (Figs 3D; 4C). Tophules are present (albeit in young thalli they are poorly distinguishable) and can be of different shapes (from obovate, ovate, to club-shaped, spherical and oblong), are 3-8 $\mathrm{mm}$ long and up to $4 \mathrm{~mm}$ broad (Figs $3 \mathrm{~B}$; $4 \mathrm{~B}$ ), and often concentrated in the tip of the main axes. Holdfast, main axes, and tophules are perennial. Primary branches are seasonal (March-June) (Mulas et al. 2019), typically smooth in the basal region and occasionally with small and widely spaced spiny appendages. Branches of higher order are more robust, show lateral spines, and their inner aerocysts are inconspicuous. Transformed ends of last order branches show spiny laterals containing receptacles (Fig. 3C). Differences in the morphology among specimens seem to be environmentally driven. For instance, subtidal specimens display shorter and robust branches densely covered with spinelike appendages and without pronounced receptacles compared to tide pool specimens that have less pronounced spines and correspond to Ramon's description (Fig. 4).

Anatomical characteristics of T. rayssiae (Ramon) M.Mulas, J.Neiva \& Á.Israel, comb. nov., cross sections corresponded to the genus Treptacantha as recently described by Orellana et al. (2019). T. rayssiae (Ramon) M.Mulas, J.Neiva \& Á.Israel, comb. nov., shows medullary cells which form a central mass, while the cortical ones having a bigger size, globose shape and thickened walls and the meristoderm is composed by a single layer of square-shaped cells (Fig. 5).

This is in accordance with the description of the genus (Orellana et al. 2019): Treptacantha often displays significant polymorphism attributable to regional, seasonal and habitat differences (e.g. genetically - confirmed Atlantic Treptacantha nodicaulis, Treptacantha sp. from Crete, T. baccata, T. barbata, T. abies-marina, T. ballesterosii and T. mauritanica) stressing that morphological differences must be supported by additional evidence, such as molecular data, before describing additional species.

\section{Species distribution}

Literature and database records suggest a disjunct geographical distribution for T. rayssiae (Ramon) M.Mulas, J.Neiva \& 

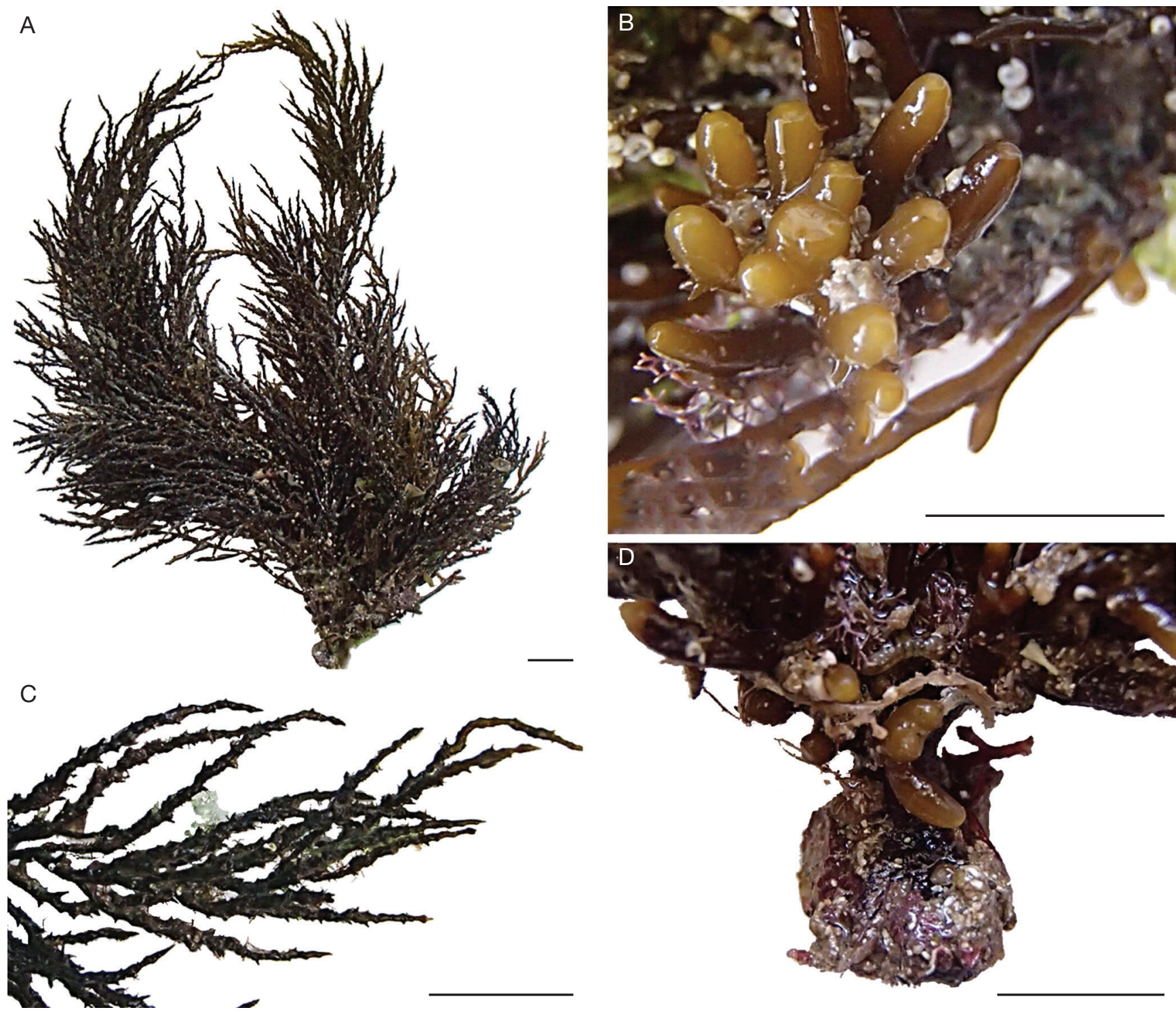

FIG. 3. - Typical morphology of Treptacantha rayssiae (Ramon) M.Mulas, J.Neiva \& Á.Israel, comb. nov., at Achziv, Israel (May 2019, voucher IOLR - AmR1652019): A, habitus of specimens; $\mathbf{B}$, apex with smooth tophules; C, detail of apical part of slightly spiny branches with receptacles; $\mathbf{D}$, holdfast. Scale bars: A, C, 2 cm; $\mathrm{B}, \mathrm{D}, 1 \mathrm{~cm}$.

Á.Israel, comb. nov., as shown in Figure 1A. Treptacantha rayssiae can be found in tide pools associated with vermetid reefs (abrasion platforms) in north Israel (Rilov et al. 2020), and as scattered individuals (in several locations), or as an extensive forest (only in one location, in Haifa) on horizontal subtidal bedrocks down to $5 \mathrm{~m}$ depth (Fig. 1B, based on Ramon 2000, Mulas et al. 2019, Peleg et al. 2019 and personal observations). In addition to Israel (Ramon 2000; Einav \& Israel 2008), T. rayssiae (Ramon) M.Mulas, J.Neiva \& Á.Israel, comb. nov., has been also recently reported from several sites in Lebanon (Nakoura, Adloun, Barbara, Ras-Chekaa) (Badreddine et al. 2018). Surprisingly, extra-Mediterranean records were also reported from one site (Dahab) in the Red Sea along the Egyptian coast of the Gulf of Aqaba (Abdel-Raouf et al. 2015) and from six sites in the Persian Gulf (Ras Tanura, Saftwah, Al Qatif, Sayhat, Ad Dammam and Al Azizayah) in Saudi Arabia (Abdel-Kareem 2009).
These extra-Mediterranean records have not been genetically confirmed. In case they are not misidentifications, three exclusive scenarios can be postulated. In the first scenario, T. rayssiae (Ramon) M.Mulas, J.Neiva \& Á.Israel, comb. nov., may be a palaeoendemic species that was formerly widespread (before the closure of the Mediterranean passages to the Indian Ocean, some 20 MYA), and is now restricted to several very small "relict" areas of its past distribution. In the second scenario, T. rayssiae (Ramon) M.Mulas, J.Neiva \& Á.Israel, comb. nov., may be a Lessepsian migrant first detected in the invaded region, the Levantine basin, and later in the origin region, the Red Sea and the Persian Gulf. These two scenarios seem unlikely because $T$. rayssiae (Ramon) M.Mulas, J.Neiva \& Á.Israel, comb. nov., and T. nodicaulis are more closely related than $T$. nodicaulis and $T$. baccata, and the two latter are estimated to have diverged around 10 MYA (Silberfeld et al. 2010), i.e., already after the closure of the 
A
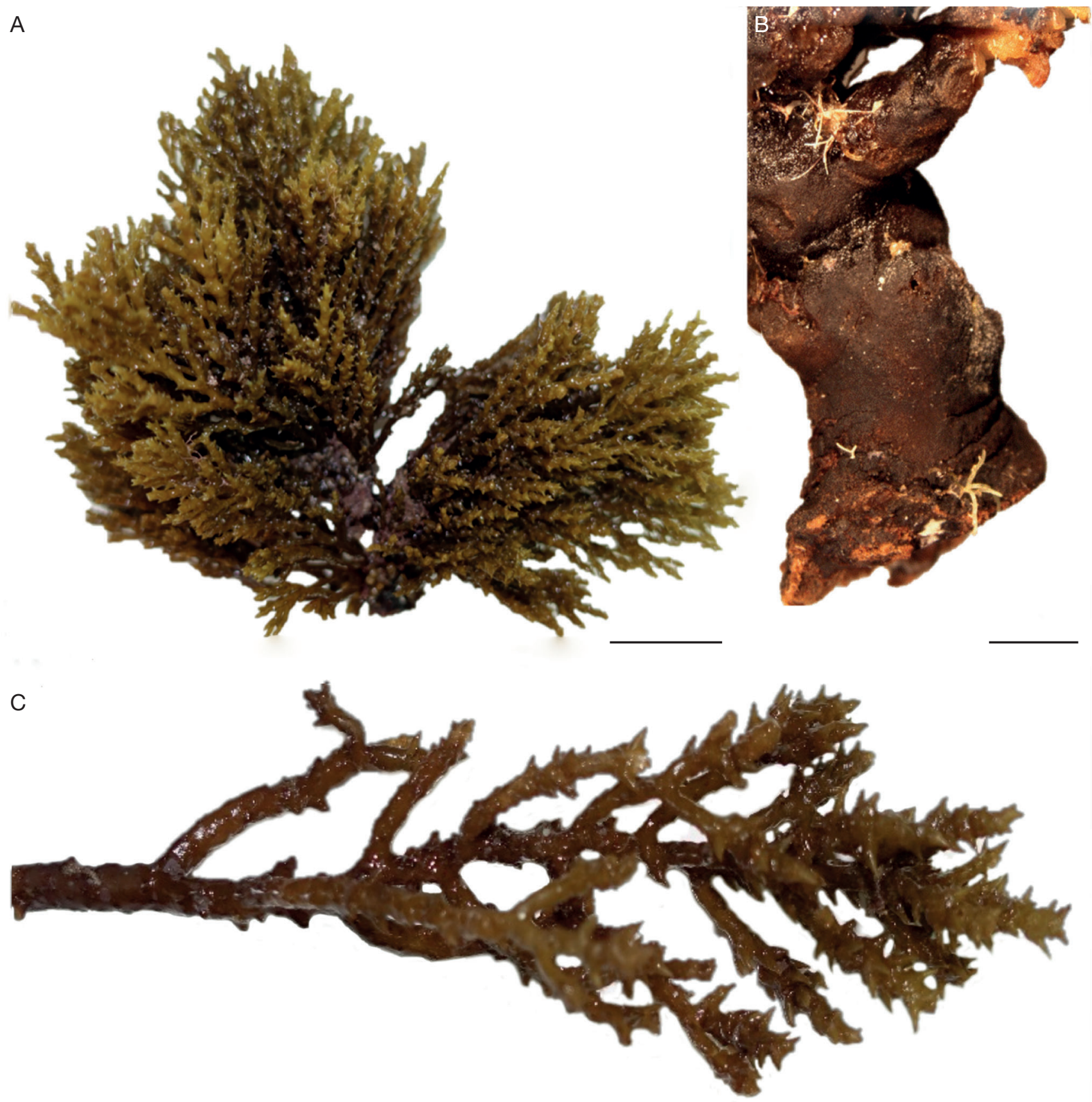

FIG. 4. - Morphology of Treptacantha rayssiae (Ramon) M.Mulas, J.Neiva \& Á.Israel, comb. nov., at Tel Shikmona, Israel (May 2018, voucher IOLR-MM00641): A, habitus of specimen; B, holdfast; C, detail of apical part of branches with receptacles, packed, cylindrical and spiny. Scale bars: A, $4 \mathrm{~cm}$; B, C, $2 \mathrm{~cm}$.

eastern Tethyan seaway (Bialik et al. 2019). Under the third scenario, T. rayssiae (Ramon) M.Mulas, J.Neiva \& Á.Israel, comb. nov., is an eastern Mediterranean endemic seaweed that has migrated to the Indo-Pacific, a rare case of anti-Lessepsian migration. It should be noted that there are only a handful examples of anti-Lessepsian species, making this last scenario also unlikely (Golani et al. 2002). Among the very few marine organisms that have moved from the Mediterranean into the Red Sea, are the fish Solea aegyptiaca Chabanaud, and six species of polychaetes (Golani et al. 2002; Faiza 2009; Chanet et al. 2012), but no macroalgal species recorded so far.
In contrast, a large number of Lessepsian macroalgae migrants have been recorded in the Mediterranean Sea along the years (Por 1971, 1978; Galil \& Zenetos 2002; Rilov \& Galil 2009; Otero et al. 2013; Boudouresque et al. 2016; Galil et al. 2017; Israel \& Einav 2017), where the last update has counted 119 alien macrophytes introduced by different sources out of a total of 613 confirmed marine organisms (Verlaque et al. 2015; Zenetos et al. 2017). All possible hypothetical scenarios to explain the extra-Mediterranean records are not supported by evidence. The main growing/reproductive season of T. rayssiae (Ramon) M.Mulas, J.Neiva \& Á.Israel, comb. nov., is winter- 

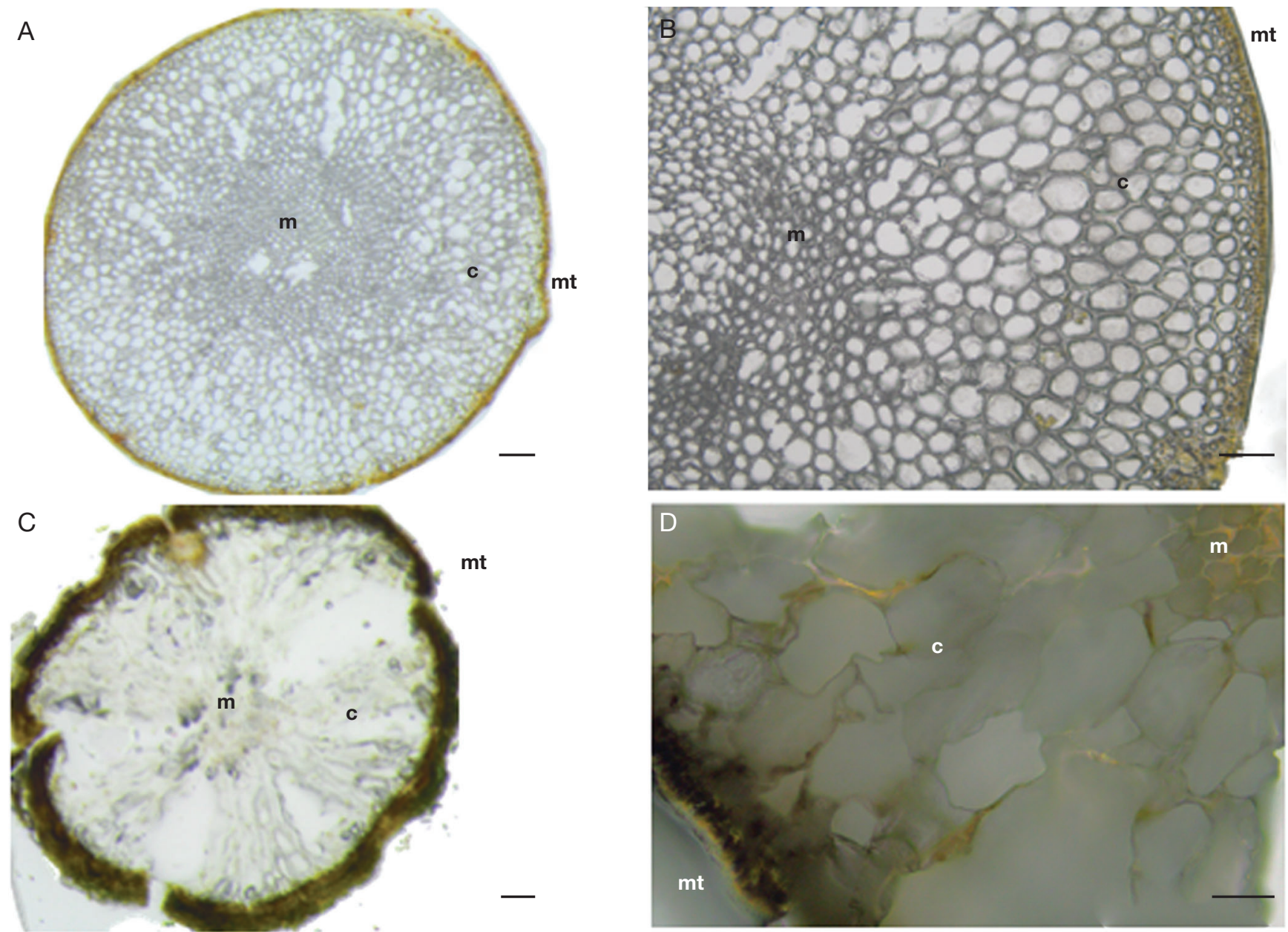

FIG. 5. - Cross sections of the thallus of Treptacantha rayssiae (Ramon) M.Mulas, J.Neiva \& Á.Israel, comb. nov.: A, primary branch; B, detail of the three vegetative tissues at Tel Shikmona; $\mathbf{C}$, primary branch; D, detail of the three vegetative tissues from Achziv. Scale bars: A, $50 \mu \mathrm{m} ; \mathrm{B}, 200 \mu \mathrm{m} ; \mathrm{C}, 100 \mu \mathrm{m} ; \mathrm{D}, 20 \mu \mathrm{m}$. Abbreviations: mt, meristoderm; c, cortex; m, medulla.

spring and not warmer summer months when the fronds are shed, and the basal perennial parts enter a dormancy period (Mulas et al. 2019). A temperate growth and reproductive window do not support a tropical origin, but seasonal shifts are also observed among tropical species. Because all three scenarios are highly unlikely, we suspect that the records from the Persian Gulf and the Red Sea (Abdel-Kareem 2009; AbdelRaouf et al. 2015) are based on misidentifications. In the study of Abdel-Kareem (2009), the photographic record has poor quality but does not resemble T. rayssiae (Ramon) M.Mulas, J.Neiva \& Á.Israel, comb. nov. In fact, in both studies of Abdel-Kareem (2009) and Abdel-Raouf et al. (2015), the taxonomical identification of T. rayssiae (Ramon) M.Mulas, J.Neiva \& Á.Israel, comb. nov. (as Cystoseira rayssiae) was based on the reference check-list of the Red Sea of Lipkin \& Silva (2002) which, however, never mentions T. rayssiae (Ramon) M.Mulas, J.Neiva \& Á.Israel, comb. nov., but rather the common fucoid Polycladia myrica (as Cystoseira myrica). This species and Syrophysalis trinodis (as Cystoseira trinodis) have also been reported from the Red Sea in other studies (e.g. Ibraheem et al. 2014). Many seaweed groups are notoriously difficult to identify, and this applies also to Cystoseira sensu lato and related genera. Thus, we conclude that the most plausible explanation is that $T$. rayssiae (Ramon) M.Mulas, J.Neiva \& Á.Israel, comb. nov., was misidentified in these studies, and the species is a unique example of a Levantine Basin endemism. If what we claim is confirmed by further analyses of Mediterranean samples, conclusively excluding it from nearby areas (Cyprus, southern Turkey and farther away), the protection of this species emerges as a priority in the Mediterranean Sea, because of the restricted local distribution and increasing pressures such as rabbitfish and sea urchin overgrazing, pollution, ocean warming and urbanization.

\section{Acknowledgements}

We thank Dar Golomb and Maura Schonwald from IOLR for field assistance, Guy Paz and Ximena Velasquez for helping with the artwork and Laura Ballatore with the French translation. MM PhD project is supported by ISF grant No 1982/16 to GR. JN has received funding from H2020 (EU) under grant agreement No 730984, Assemble Plus, and work at CCMAR was funded by FCT - Foundation for Science and Technology (Portugal) UID/Multi/04326/2019, Biodiversa/0004/2015, 
SFRH/BPD/88935/2012 (DL 57/2016/CP1361/CT0010), SFRH/BSAB/150485/2019, and a Pew Marine Fellowship. AI and SS thank The National Herbarium of The Hebrew University (HUJ) for access to preserved seaweed specimens. $\mathrm{AI}$ also thanks the Ministry of Science $\&$ Technology, Israel; Ministry of Health, Israel and Ministry of Energy Infrastructure and Water Resources, Israel, for support. All the authors thank Pr Michael Guiry for the validation of the new taxonomical combination. A final thanks to the associate editor, Stacy Krueger-Hadfield, and the two anonymous reviewers who improve the quality of our paper.

\section{REFERENCES}

Abdel-Kareem M. S. M. 2009. - New algal records from the Arabian Gulf coast of Saudi Arabia. Botany Research International 2 (4): 268-276.

Abdel-Raouf N., Al-Enazi N. M., Al-Homaidan A. A., Ibrahee, I. B. M., Al-Othman M. R. \& Hatamieh A. A. 2015. Antibacterial $\beta$-amyrin isolated from Laurencia microcladia. Arabian Journal of Chemistry 8 (1): 32-37. https://doi.org/10.1016/j. arabjc.2013.09.033

Amaral-Zettler L. A., Dragone N. B., Schell J., Slikas B., Murphyl.G., Morral C. E. \& ZetTler E. R. 2017. — Comparative mitochondrial and chloroplast genomics of a genetically distinct form of Sargassum contributing to recent "Golden Tides" in the Western Atlantic. Ecology and Evolution 7 (2): 516-525. https://doi.org/10.1002/ece3.2630

Badreddine A., Abboud-Abi SaAb M., Gianni F., Ballesteros E. \& MANGialajo L. 2018. - First assessment of the ecological status in the Levant Basin: Application of the CARLIT index along the Lebanese coastline. Ecological Indicators 85: 37-47. https:// doi.org/10.1016/j.ecolind.2017.10.006

BANDELT H. J., FORSTER P. \& RÖHL A. 1999. — Median-joining networks for inferring intraspecific phylogenies. Molecular Biology and Evolution 16 (1): 37-48. https://doi.org/10.1093/ oxfordjournals.molbev.a026036

BARICHE M. 2006. - Diet of the Lessepsian fishes, Siganus rivulatus and S. luridus (Siganidae) in the eastern Mediterranean: a bibliographic analysis. Cybium 30 (1): 41-49.

Benson D. A., Cavanaugh M., Clark K., Karsch-Mizrachi I., LipMAN D. J., Ostell J. \& SAYERS E. W. 2017. — GenBank. Nucleic Acids Research 45: D37-D42. https://doi.org/10.1093/nar/gkw1070

Bialik O. M., Frank M., Betzler C., Zammit R. \& Waldmann N. D. 2019. - Two-step closure of the Miocene Indian Ocean Gateway to the Mediterranean. Scientific Reports-UK9 (1): 1-10. https:// doi.org/10.1038/s41598-019-45308-7

Bouafif C., Verlaque M. \& Langar H. 2016. - New contribution to the knowledge of the genus Cystoseira C. Agardh in the Mediterranean Sea, with the reinstatement of species rank for C. schiffneri Hamel. Cryptogamie Algologie 37 (2): 133-154. https://doi.org/10.7872/crya/v37.iss2.2016.133

Boudouresque C. F., Perret-Boudouresque M. \& Verlaque M. 2016. - Donor and recipient regions for exotic species of marine macrophytes: a case of unidirectional flow, the Mediterranean Sea, in $41^{\text {th }}$ CIESM Congress Proceeding: Rapport de la Commission Internationale pour l'Exploration Scientifique de la Mer Méditerranée. CIESM, Monaco: 426.

Bruno de Sousa C., Cox C. J., Brito L., Pavão M. M., Pereira H., Ferreira A., Ginja C., Campino L., Bermejo R., Parente M. \& VARELA J. 2019. - Improved phylogeny of brown algae Cystoseira (Fucales) from the Atlantic-Mediterranean region based on mitochondrial sequences. PLoS ONE 14 (1): e0210143. https:// doi.org/10.1371/journal.pone.0210143
Bulleri F., Benedetti-Cecchi L., Acunto S., Cinelli F. \& HAWKINS S. J. 2002. - The influence of canopy algae on vertical patterns of distribution of low-shore assemblages on rocky coasts in the northwest Mediterranean. Journal of Experimental Marine Biology and Ecology 267: 89-106. https://doi.org/10.1016/ S0022-0981(01)00361-6

Chanet B., Desoutter-Meniger M. \& Bogorodsky S. V. 2012. - Range extension of Egyptian sole Solea aegyptiaca (Soleidae: Pleuronectiformes), in the Red Sea. Cybium 36 (4): 581-584. https://doi.org/10.26028/cybium/2012-364-012

Cheminé́ A., Sala E., Pastor J., Bodilis P., Thiriet P., MangiaLAJO L., CotTAlorda J.-M. \& FranCOUR P. 2013. - Nursery value of Cystoseira forests for Mediterranean rocky reef fishes. Journal of Experimental Marine Bioogy and Ecology 442: 70-79. https://doi.org/10.1016/j.jembe.2013.02.003

Cormaci M., Furnari G., Catra M., Alongi G. \& Giaccone G. 2012. - Flora marina bentonica del Mediterraneo: Phaeophyceae. Bollettino dell'Accademia Gioenia Scienze Naturale 45: 1-508.

Darriba D., Taboada G. L., Doallo R. \& Posada D. 2012. jModelTest 2: more models, new heuristics and parallel computing. Nature Methods 9: 772. https://doi.org/10.1038/nmeth.2109

DoueK J., Barki Y., Gateno D. \& RinkeVich B. 2002. —Possible cryptic speciation within the sea anemone Actinia equina complex detected by AFLP markers. Zoological Journal of the Linnean Society-London 136 (3): 315-320. https://doi.org/10.1046/j.10963642.2002.00034.x

Draisma S. G. A., Ballesteros E., Rousseau F. \& Thibaut T. 2010. - DNA sequence data demonstrate the polyphyly of the genus Cystoseira and other Sargassaceae genera (Phaeophyceae). Journal of Phycology 46 (6): 1329-1345. https://doi.org/10.1111/ j.1529-8817.2010.00891.x

EINAV R. \& ISRAEL A. 2008. - Checklist of seaweeds from the Israeli Mediterranean: Taxonomical and ecological approaches. Israel Journal of Plant Sciences 56 (1): 127-191.

FAIZA A. A.-E. 2009. - New records of polychaetes from the south part of Suez Canal, Egypt. World Journal of Fish and Marine Sciences 1 (1): 7-19.

Galil B. S. \& Zenetos A. 2002. - A Sea Change - Exotics in the Eastern Mediterranean Sea, in LEPPAKOSKI E., GOLLASH S. \& Olenin S. (eds), Invasive Aquatic species of Europe - distribution impacts and management. Kluwer Academic Publishers, London: 1-19. https://doi.org/10.1007/978-94-015-9956-6_33

Galil B., Marchini A., Occhipinti-Ambrogi A. \& Ojaveer H. 2017. - The enlargement of the Suez Canal - Erythraean introductions and management challenges. Management of Biological Invasions 8 (2): 141-152. https://doi.org/10.3391/mbi.2017.8.2.02

Golani D., Orsi-Relini L., Massuti E. \& Quignard J. P. 2002. CIESM. Atlas of Exotic Species in the Mediterranean. Vol. 1. Fishes. CIESM, Monaco, $256 \mathrm{p}$.

Ibraheem I. B. M., Alharbi R. M., Abdel-Raouf N. \& AL-ENAZI N. M. 2014. - Contributions to the study of marine algae inhabiting Umluj Seashore, Red Sea. Beni-Suef University Journal of Basic and Applied Sciences 3 (4): 278-285. https://doi. org/10.1016/j.bjbas.2014.11.001

ISRAEL A. \& EINAV R. 2017. - Alien seaweeds from the Levant basin (Eastern Mediterranean Sea), with emphasis to the Israeli shores. Israel Journal of Plant Sciences 64: 99-110.

LIPKIN Y. \& SiLVA P. 2002. - Marine algae and seagrasses of the Dahlak Archipelago, southern Red Sea. Nova Hedwigia 75 (1-2): 1-90. https://doi.org/10.1127/0029-5035/2002/0075-0001

LundBerg B., OfgoreK R., Galil B. \& Goren M. 1999. Algal food of siganid fishes in Shiqmona, Israel. Israel Journal of Zoology 45: 314.

MCDEVIT D. C. \& SAunders G. W. 2009. — On the utility of DNA barcoding for species differentiation among brown macroalgae (Phaeophyceae) including a novel extraction protocol. Phycological Resarch 57 (2): 131-141. https://doi.org/10.1111/j.14401835.2009.00530.x 
Mineur F., Arenas F., Assis J., Davies A., Engelen A. H., Fernandes F., Malta E. J., Thibaut T., Van Nguyen T., Vaz-Pinto F., Vranken S., Serrâo E. A. \& de Clerk O. 2015. - European seaweeds under pressure: Consequences for communities and ecosystem functioning. Journal of Sea Research 98: 91-108. https://doi.org/10.1016/j.seares.2014.11.004

Mulas M., Silverman J., Israel A., Golomb D. \& Rilov G. 2019. - Marine algal forests in the Levantine Basin: the case of Cystoseira rayssiae along the Israeli coast, in Proceedings of the $\sigma^{\text {th }}$ Mediterranean Symposium on Marine Vegetation. UNEP/ MAP-RAC/SPA, Antalya, 155 p.

Orellana S., Hernandez M. \& Sansón M. 2019. - Diversity of Cystoseira sensu lato (Fucales, Phaeophyceae) in the eastern Atlantic and Mediterranean based on morphological and DNA evidence, including Carpodesmia gen. emend. and Treptacantha gen. emend. European Journal of Phycology 54 (3): 447-465. https://doi.org/10.1080/09670262.2019.1590862

Otero M., Cebrian E., Francour P., Galil B. \& Savini D. 2013. - Monitoring marine invasive species in Mediterranean Marine Protected Areas (MPAs): A strategy and practical guide for managers. IUCN. Malaga, Spain, $136 \mathrm{p}$.

Peleg O., Guy-Haim T., Yeruham E., Silverman J., Rilov G. 2019. - Tropicalization may invert trophic state and carbon budget of shallow temperate rocky reefs. Journal of Ecology, 00: 1-11. https://doi.org/10.1111/1365-2745.13329

POR F. D. 1971. - One hundred years of Suez Canal - A century of Lessepsian migration: Retrospect and viewpoints. Systematic Biology 20 (2): 138-159. https://doi.org/10.2307/2412054

POR F. D. 1978. - Lessepsian Migration. The Influx of Red Sea Biota into the Mediterranean by way of the Suez Canal. Ecological Studies. Berlin. https://doi.org/10.1007/978-3-642-66728-2

RAMON E. 2000. - Cystoseira rayssiae - a new Cystoseira (Cystoseiraceae, Fucophyceae) from the shores of Israel, Eastern Mediterranean Sea. Israel Journal of Plant Sciences 48 (1): 59-65.

Rilov G. \& GALIL B. 2009. - Marine bioinvasions in the Mediterranean Sea - History, distribution and ecology, in RILOV G. \& CROOKS J. A. (eds), Biological Invasions in Marine Ecosystems: Ecological, Management, and Geographic Perspectives. Springer, Berlin Heidelberg: 549-575. https://doi.org/10.1007/978-3-540-79236-9

RiLOV G. 2016. - Multi-species collapses at the warm edge of a warming sea. Scientific Reports 6: 36897. https://doi.org/10.1038/ srep36897

Rilov G., Peleg O., Yeruham E., Levy G. \& Rave O. 2018. Alien turf: Overfishing, overgrazing and invader domination in south-eastern Levant reef ecosystems. Aquatic Conservation 28 (2): 351-369. https://doi.org/10.1002/aqc.2862

Rilov G., Peleg O., Guy-Haim T. \& Yeruham H. 2020. Community dynamics and ecological shifts on Mediterranean vermetid reefs. Mediterranean Marine Research, 105045. https:// doi.org/10.1016/j.marenvres.2020.105045

Ronquist F., Teslenko M., Van Der Mark P., Ayres D. L., Darling A., Höhna S., Larget B., Liu L., Suchard M. A. \&
HuelsenbeCK J. P. 2012. - MrBayes 3.2: Efficient Bayesian phylogenetic inference and model choice across a large model space. Systematic Biology 61 (3): 539-542. https://doi.org/10.1093/ sysbio/sys029

Sala E., Kizilkaya Z., Yildirim D. \& Ballesteros E. 2011. Alien marine fishes deplete algal biomass in the Eastern Mediterranean. PLoS ONE 6 (2): e17356. https://doi.org/10.1371/ journal.pone.0017356

Silberfeld T., Leigh J. W., Verbruggen H., Cruand C., De ReViERS B. \& RousSEAU F. 2010. - A multi-locus time-calibrated phylogeny of the brown algae (Heterokonta, Ochrophyta, Phaeophyceae): Investigating the evolutionary nature of the "brown algal crown radiation'. Molecular Phylogenetics and Evolution 56 (2): 659-674. https://doi.org/10.1016/j.ympev.2010.04.020

TAșKin E., Jahn R., ÖZTÜrK M., Furnari G. \& CORMaCi M. 2012. - The Mediterranean Cystoseira (with photographs). Celar Bayar University, Manisa: 1-75.

Thibaut T., Blanfuné A., Boudouresque C. F. \& Verlague M. 2015. - Decline and local extinction of Fucales in the French Riviera: The harbinger of future extinctions. Mediterranean Marine Science 16 (1): 206-224. https://doi.org/10.12681/mms.1032

UNEP/MAP-RAC/SPA 2012. - Annex II. Protocol Concerning Specially Protected Areas and Biological Diversity in the Mediterranean. List of Endangered or Threatened Species.

VALDAZO J., RoDRİGUEZ-RODRİGUEZ M. A., ESPINO F., HAROUN E. \& TUYA F. 2017. - Massive decline of Cystoseira abies-marina forests in Gran Canaria Island (Canary Islands, eastern Atlantic). Scientia Marina 81 (4): 499-507. https://doi.org/10.3989/ scimar.04655.23A

Vergés A., Steinberg P. D., Hay M. E., Poore A. G. B., CampBell A. H., Ballesteros E., Heck K. L. J., Booth D. J., Coleman M. A., Feary D. A., Figuera W., Langlois T., Marzinelli E. M., MizereK T., Mumby P. J., NaKamura Y., Roughan M., Van Sebille E., Sen Gupta A., Smale D. A., Tomas F., WernberG T. \& Wilson S. K. 2014a. - The tropicalization of temperate marine ecosystems: Climate-mediated changes in herbivory and community phase shifts. Proceedings of the Royal Society B: Biological Sciences 281 (1789): 20140846. https://doi.org/10.1098/rspb.2014.0846

Vergés A., Tomas F., Cebrian E., Ballesteros E., Kizilkaya Z., Dendrinos P., Karamanlidis A. A., Spiegel D. \& Sala E. 2014b. - Tropical rabbitfish and the deforestation of a warming temperate sea. Journal of Ecology 102 (6): 1518-1527. https:// doi.org/10.1111/1365-2745.12324

Verlaque M., Ruitton S., Mineur F. \& Boudouresque C.-F. 2015. - CIESM. Atlas of Exotic Species in the Mediterranean Sea. Vol. 4 Macrophytes. CIESM, Monaco, 364 p.

Zenetos A., Çinar M.E., Crocetta F., Golani D., Rosso A., Servello G., Shenkar N., Turon X. \& Verlaque M. 2017. Uncertainties and validation of alien species catalogues: The Mediterranean as an example. Estuarine Coastal and ShelfScience 191: 171-187. https://doi.org/10.1016/j.ecss.2017.03.031 


\section{APPENDICES}

APPENDIX 1. - Bayesian 50\% majority-rule consensus COI tree of Treptacantha Kützing (sensu Orellana et al. (2019) synonym of Cystoseira C.Agardh clade VI of Draisma et al. (2010), unique sequences only), showing the phylogenetic position of $T$. rayssiae (Ramon) M.Mulas, J.Neiva \& Á.Israel, comb. nov. Bayesian posterior probabilities $(>0.50)$ and maximum likelihood bootstrap support values, respectively. The outgroup used is T. abies-marina (S.G.Gmelin) C.Agardh, the most divergent of the genus (Bruno de Sousa et al. 2019). Scale bar: 0.006 BIPP (Bayesian Inference Posterior Probability).

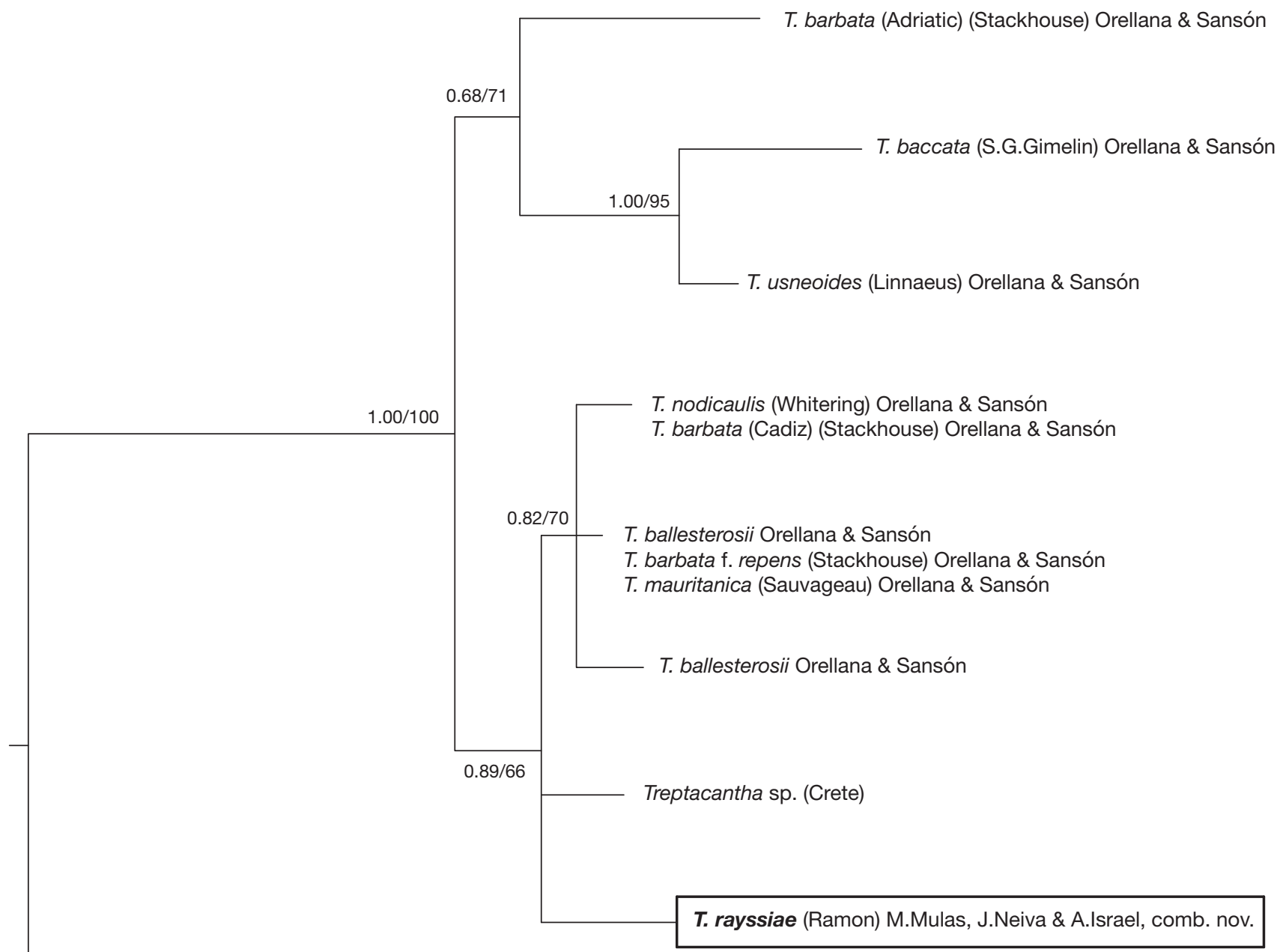

T. abies-marina (S.G.Gimelin) C.Agardh 
APPENDIX 2. - Sequences extracted from GenBank (Bruno de Sousa et al. 2019; Silberfeld et al. 2010†; McDevit \& Saunders 2009ł). The dash between the COI GenBank accession numbers indicates the first and the last sequence in the included range.

COI

Treptacantha mauritanica

Treptacantha barbata f.

Treptacantha barbata

Treptacantha nodicaulis

Treptacantha baccata

Treptacantha usneoides

Treptacantha baccata

Treptacantha usneoides

GenBank accession n'

EU681394†

FJ409138‡

MF768036-44

MF768045-47

MF768048-49

MF768050-52

EU681401†, MF768053-63

MF768064-65

MF768066-71

MF768072

MF768073 sequences

KY682970, MF768075

EU681400†, MF768076-77

EU681399†, MF768078-79

MF768080-83

EU681399†, MF768078-79

MF768080-83

1
1
8
3
2
3
12
2
6
1
1
1
2
3
3
4
3
4

